WellBeing International

WBI Studies Repository

2000

\title{
The Status of Animals in Biblical and Christian Thought: A Study in Colliding Values
}

Rod Preece

Wiflrid Laurier University

David Fraser

University of British Columbia

Follow this and additional works at: https://www.wellbeingintlstudiesrepository.org/morrphi

Part of the Animal Studies Commons, Ethics and Political Philosophy Commons, and the Other Anthropology Commons

\section{Recommended Citation}

Preece, R., \& Fraser, D. (2000). The status of animals in Biblical and Christian thought: A study in colliding values. Society \& Animals, $8(3), 245-263$.

This material is brought to you for free and open access by WellBeing International. It has been accepted for inclusion by an authorized administrator of the WBI Studies Repository. For more information, please contact wbisr-info@wellbeingintl.org.

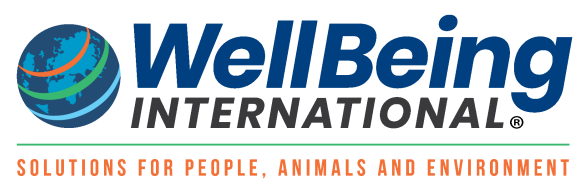




\title{
The Status of Animals in Biblical and Christian Thought: A Study in Colliding Values
}

\author{
Rod Preece and David Fraser ${ }^{1}$
}

\begin{abstract}
A common contemporary view is that the Bible and subsequent Christian thought authorize humans to exploit animals purely as means to human ends. This paper argues that Biblical and Christian thought have given rise to a more complex ethic of animal use informed by its pastoralist origins, Biblical pronouncements that permit different interpretations, and competing ideas and doctrines that arose during its development, and influenced by the rich and often contradictory features of ancient Hebrew and GrecoRoman traditions. The result is not a uniform ethic but a tradition of unresolved debate. Differing interpretations of the Great Chain of Being and the conflict over animal experimentation demonstrate the colliding values inherent in the complex history of Biblical and Christian thought on animals.
\end{abstract}

Recent secular interpretations have tended to portray Biblical and Christian thought as encouraging the domination and exploitation of nonhuman animals. For example, Edward Payson Evans, Lynn White Jr., Peter Singer, and Roderick Frazier Nash, ${ }^{2}$ among many others, have interpreted the Genesis account of creation as the beginning of Judeo-Christian oppression of animals and nature. In Genesis, God gave humankind "dominion over the fish of the sea, and over the fowl of the air, and over the cattle, and over all the earth, and over every creeping thing that creepeth upon the earth." ${ }^{3}$ This is often read as God's granting a license to treat animated nature as a mere means to human ends. Genesis is the origin, it is frequently argued, of a consistent Christian disregard for the value and well being of animals. Thus, White interpreted the Biblical creation story to mean that God had planned all of nonhuman nature, "explicitly for man's benefit and rule: no item in the physical creation had any purpose but to serve man's purposes." And Singer prefaced his account of Christian thought regarding animals with the statement: "To end tyranny we must first understand it."

It is our contention, however, that such interpretations constitute a misreading of Genesis, that they ignore traditional understanding of Biblical passages regarding animals, and that they fail to recognize the complexity of the development of animal ethics in the Christian tradition. We do not contend that the tradition has consistently acknowledged the inherent worth of animals or has led to satisfactory treatment of animals. Rather, it is a complex and inchoate tradition in which the status and appropriate treatment of animals have been repeatedly discussed and debated.

\section{Animals in the Scriptures}

It was one of Karl Marx's more perceptive insights, later borrowed by determinist sociologists in general, that a society's values and ideas reflect primarily the self-serving demands of the society's economic organization. According to that view, attitudes to animals in Christian thought must first be understood in 
the context of the pastoralist culture in which they arose. The pastoralist economy hinges on the use of domestic animals as repositories of wealth, sources of food, and items of trade. In Marxian analysis, animals must be viewed as possessions that can be used for human purposes; moreover, for pastoralists to prosper, perhaps even to survive, these living possessions must be treated with appropriate care.

What Marxian economic determinism obscures from our view is that this balance between ownership and care was achieved in early Biblical thought by granting animals a special status. Unlike human artifacts such as the hoe and the plough, animals were seen as having been created by God and entrusted to humans for care in a relationship that the translators of the Bible into English termed "dominion," a translation that does scant justice to the Hebrew term rādâ. ${ }^{4}$

This term can be interpreted in two ways. One is a kind of despotic domination such as the subjugation of one people by their enemies (Judges 14:4; Nehemiah 9:28). The other, as John Passmore notes, would imply treating animals "in a manner of a good shepherd, anxious to preserve them in the best possible condition for his master." In the second sense, "dominion" was also used to describe God's relationship with the world (Psalm 72:8). Writers such as White and Singer evidently assume that the dominion granted to humans in Genesis implied despotic subjugation. According to Andrew Linzey, however, this interpretation "conflicts with a great deal of scholarly evidence." Linzey points out that human dominion over other creatures was granted in the context of creating humans in God's image. In that context, humans were intended to share not only some of God's prerogative but also, in Linzey's words, "his moral nature", acting toward creation as God had done, bringing order to chaos and bringing blessing and goodness, not tyrannical mastery, to the world. ${ }^{6}$

Indeed, that was the more customary historical interpretation of "dominion." In Seasons of 1728, James Thomson, former divinity student, understood our role as "the Lord and not the Tyrant of the world." In Self-Interpreting Bible of 1776 John Brown, the staid Biblical traditionalist, declared it an "honourable dominion over the creatures." "Gentle dominion," avowed George Nicholson in his 1801 On the Primeval Diet of Man. In 1802, Joseph Ritson described the dominion of Genesis as instituted, "for the sake of authority, protection, and the glorious offices of benevolence and humanity." In her popular novel Agnes Grey (1847) Anne Brontë insisted that the passage, together with other Biblical texts, implied a significant human responsibility to what she called our fellow "sentient creatures," although her commentary also showed how the issue was a cause of constant dispute between the compassionate and the selfish. Other commentators too saw the message of stewardship and responsibility extending well beyond Genesis. Thus, in An Essay on Humanity to Animals (1798), the Anglican priest, Thomas Young, cites passages from Exodus, Leviticus, Numbers, Deuteronomy, Proverbs, Jonah, St. Matthew and 1 Corinthians to argue that God cares for the animal realm and requires us to do likewise. Victor Hugo, a Roman Catholic, tells us in Les Misérables (1862) that according to St. Matthew "duty to all living creatures" is one of the four duties of humankind. ${ }^{7}$

The scriptures, particularly the Old Testament, repeatedly reinforced the care aspect of the relationship. For the great King David, an early indication of his suitability as a monarch was his diligence and courage in protecting his father's sheep (1 Samuel 17:35). Later, when the prophet Nathan rebuked David for abusing his power, he did so by first telling a story about a poor man who lavished care and affection on a lamb (2 Samuel 12:2), thus not only evoking David's sympathy but also reminding him of the proper relationship of monarch to subject. When God selected Rebecca as the wife of Isaac and the mother of her nation, the sign that she had been chosen was her willingness, when asked for water by a thirsty stranger, to water his camels as well, "until they have had enough" (Genesis 24:19) - itself no mean feat. Indeed, a conscientious shepherd protecting a flock of sheep was such a positive image that it became a common metaphor for divine goodness (Psalm 23:1-4), and sometimes descriptions of divine love even began to sound like lessons in animal husbandry: 
For these are the words of the Lord God: Now I myself will ask after my sheep and go in search of them. As a shepherd goes in search of his sheep when his flock is dispersed all around him, so will I go in search of my sheep and rescue them no matter where they were scattered. . . . I myself will tend my flock, I myself pen them in their fold, says the Lord God. I will search for the lost, recover the straggler, bandage the hurt, strengthen the sick, leave the healthy and strong to play, and give them their proper food. Ezekiel 34:11-16 (The New English Bible)

Thus, the pastoralist culture of the Bible could hardly be described, other than for ideological reasons, as encouraging ruthless exploitation of animals. It was, rather, a culture that recognized animals both as possessions who can be used and killed for human purposes and, at the same time, as wards entrusted by God to humans for diligent care.

These two elements, though making sense in a pastoralist context, may appear contradictory in later historical contexts, and perhaps this seeming contradiction has encouraged many modern scholars to emphasize one element, usually the first, at the expense of the other. Perhaps the very existence of this tension, heightened by the plausibility of different interpretations of Biblical texts has encouraged an ongoing debate in the Christian tradition.

A third element also important in Christian thought, if less stressed in Biblical texts, furthers this tension. The scriptures and later Christian philosophy sometimes treat animals not merely as living possessions deserving diligent care but, by a relationship bordering on kinship, as close links to humankind - partly because both humans and other species came into existence as works of God. Thus, the writer of Ecclesiastes (3:18-20) noted that humans and animals alike are created from dust, return to dust, and that "all draw the same breath." Isaiah (11:6-8) describes a kinship utopia in which the wolf dwells with the lamb, the leopard lies with the fatling, and the child has no fear of the asp.

Unlike the often quoted account of creation in the more recent P-narrative (Genesis 1), in which humans are told to "subdue" the earth and have "dominion" over other species, the older J-narrative (Genesis 2) presents a very different view of the human-animal relationship. In The Yahwist's Landscape, Theodore Hiebert explained that P's view is conspicuously hierarchical. At creation, God commands humans to rule (rādâ), to exercise dominion over other animate life (1.28).

Whether one wishes to construe such rule as benevolent or harsh - and both are possible within the limits of the term in biblical usage - there can be no doubt that rādâ represents control and power, since it is used customarily of kings and always of those with authority over others. By contrast, $\mathrm{J}$ conceives of this relationship in terms that are more communal. As animals and humans alike are made from the earth's topsoil, they possess no distinct ontological status, both being referred to simply as living beings ... 8

In the J-narrative, we read that God placed the first man in the garden and then, out of concern that the man was alone, formed the animals and the birds and brought them to him, though none proved to be a fully satisfactory companion. Later, God's promise never again to flood the earth took the form of a covenant made not only with humans but with all animals as well (Genesis 9:9-17).

Other passages explicitly extend human moral requirements beyond those of pastoralist husbandry. The Talmud tells us, "It is forbidden, according to the law of Torah, to inflict pain upon any living creature, even if it is ownerless," thus indicating that our responsibilities extend to animalkind in general, not only to animals as possessions. The writer of Proverbs (12:10) tells us that it is a "righteous" person (not merely a prudential one) who avoids cruelty and "regardeth the life of his beast." Moreover, the Book of Enoch (7:4-5), a Judaic text of around A.D. $150,{ }^{9}$ almost certainly based on earlier sources, tells us that it was 
only after the flood that humans "began to sin against birds and beasts and reptiles and fish, and to devour one another's flesh and to drink the blood." Early Christians accepted The Book of Enoch as one of the Holy Scriptures. ${ }^{10}$ A fourth century Bishop of Constantinople, John Chrysostom, proclaimed: "Surely we ought to show other [species] great kindness and goodness for many reasons, but above all because they are of the same origin as ourselves." ${ }^{11}$

Many animal-oriented Biblical passages pertain to domestic animals, which is scarcely surprising in a pastoralist context. Biblical references to wild animals are often less positive. For example, David was celebrated for having killed wild animals when necessary to protect his father's sheep. Nonetheless, various passages portray wild animals as also important to God. Psalm 104, for example, portrays God as having created the earth for the bene.t of wild animals and birds as much as for humans and their domestic herds and flocks. Moreover, in the speech to Job from the whirlwind, God uses a series of rhetorical questions to illustrate divine care for species of animals that are of no utility to humans. God asks, for example, "Who provides the raven with its quarry when its fledglings croak for lack of food? Do you know when the mountain-goats are born or attend the wild doe when she is in labour? . . Who has let the wild ass of Syria range at will and given the wild ass of Arabia its freedom?" (Job 38:41; Job 39:1 \& 5, New English Bible).

Some of those of faith have described a sense of kinship with animals a derivable not only from the scriptures but also from reason (John Locke), or from the intuitions of the human soul (Dostoevsky and Tolstoy). Carl Gustav Jung describes it as resting "on the deeper foundations of a primitive attitude of mind - on an unconscious identity with animals." ${ }^{12}$ These thinkers and authors of the scriptural passages just cited believe that a form of kinship links animals to us, that animals are more than just our wards, and are worthy of concern in their own right.

\section{The Great Chain of Being}

In the development of Christian animal ethics many traditional legends emphasizing our relationship to the animal realm were Christianized and localized. Androcles and the lion, for example, became St. Jerome and the lion in the west, St. Sergey and the bear in the east. Many of the saints were known by, and sometimes sanctified for, their animal relationships. Along with the famed case of St. Francis of Assisi, we find, for example, Blaise as patron saint of sick cattle, who gave sanctuary to wild animals, Gall as patron saint of birds, who shared his cave dwelling with a bear, and numerous other instances. ${ }^{13}$ This does not dispel the colliding values inherent in Christian thought. A loving father may well have related St. Jerome and the lion to his children of an evening before visiting the churchyard the next day to participate in a cockfight more or less sanctioned by the clergy. ${ }^{14}$

It is, however, with the development of the idea of the Great Chain of Being (scala naturae) - described by Arthur O. Lovejoy as "one of the half-dozen most potent and persistent presuppositions in Western thought" ${ }^{15}$ - that we encounter most clearly the inherent tension in attitudes to animals. The concept had its origins in classical Greece but was first systematized by the vegetarian, Plotinus, in the third century A.D., and it came to the fore in the early Middle Ages, dominating Western thought until the latter half of the eighteenth century. The doctrine arranges everything in nature hierarchically in its appropriate niche, from the angels through humankind (in some versions with Europeans before Asians, Amerindians, and Africans and men before women) to the higher mammals to the lowest insects.

In recent scholarship, the negative elements of the Great Chain have been emphasized, claiming that the doctrine differentiated superior humans from lesser creatures and that humans were free to use animals at their whim. David Maybury-Lewis asserts that in the chain, "man . . . was most perfect," which persuaded "man . . . that the natural world was his to exploit." ${ }^{16}$ Richard Milner tells us that the scale 
treated the inferior realm as "base."17 The doctrine, so we are led to believe, was oppressive of other species. And so it was in some cases. François Fénelon (1615-1715), theologian Archbishop of Cambrai, used the phrase, "more perfect," to describe human superiority. In addition, Fénelon followed Aristotle and Aquinas in asserting, "in nature not only the plants but the animals are made for our use." ${ }^{18}$ Cornelius a Lapide (1567-1637), a Flemish Jesuit, went even further, announcing, "lice, flies, maggots and the like were not created directly by God but by spontaneous generation, as lice from sweat." ${ }^{19}$ Such creatures were so beyond significance in the scale that God would not have deigned to create them.

It is, however, a gross misreading of the scala naturae to deem it a consistent repudiation of the worth of animals. The writings of Macrobius, Cardinal Bellarmino, and Leibniz ${ }^{20}$ emphasized the proximity to each other of the beings of the chain. In Instinct Displayed (1811) the Quaker, Priscilla Wakefield, used the idea of the chain to argue the case for our responsibilities to other creatures. ${ }^{21}$ In the Essay Concerning Human Understanding (1690), the Puritan, John Locke, laid stress on nonhuman reason and the linkage of everything in nature:

There are some Brutes, that seem to have as much Knowledge and Reason as some that are called Men; and the Animal and Vegetable Kingdoms are so nearly join'd, that if you will take the lowest of one, and the highest of the other, there will scarce be perceived any great difference between them; and so on till we come to the lowest and most inorganical parts of Matter, we shall see everywhere, that the several Species are linked together, and differ but in almost insensible degrees. ${ }^{22}$

In Thoughts Concerning Education (1693), Locke draws the appropriate conclusions and insists that children should be raised to abhor the mistreatment of "sensible," that is, sentient, creatures. In Essay on Man (1734), Alexander Pope, a Roman Catholic, writes that the interdependence of human and animal should be stressed:

Vast chain of being, which from God began. . . Connects each being, greatest with the least; Made Beast in aid of Man, and Man of Beast; All serv'd, all serving! Nothing stands alone; The Chain holds on, and where it ends, unknown. (1.8.5 and 3.1.22-26)

In Metamorphose der Tiere (1819), Johann Wolfgang von Goethe states explicitly: "Each animal is an end in itself (Zweck sein selbst ist jegliches Tier)." Goethe followed Leibniz and Spinoza in arguing that each animal species is in itself an instance of perfected design, in contrast to the view of Fénelon and others that perfection increases as we move higher in the Great Chain. The continuity of nature was an important theme for Goethe who invested considerable energy in anatomical research to prove that there is no significant discontinuity between humans and other species. Moreover, Nicholas Boyle, Goethe's finest biographer, goes so far as to assert that after 1783 , for Goethe, "the supreme religious issue is not the relation between men and gods . . . but the relation between man and animals." ${ }^{23}$

In the late eighteenth century, the poetry of the devout and mystical William Blake and the Divine Love and Wisdom of the equally devout and mystical William Swedenborg emphasized an anti-rationalist appreciation of the animal realm, apparently unconstrained by the Great Chain concept. Nonetheless, the dominant theological influence in the late eighteenth century and in much of the nineteenth century was William Paley's "Theory from Design," which greatly resembled the Great Chain of Being and could be used, like the Chain itself, to elevate or demean the animal realm. Explicitly in the writings of John Ray (a pre-Paleyan exponent of the theory), Gilbert White, and William Cowper, we find the theory employed to raise the status of animals. ${ }^{24}$ 
Thus, it is unwarranted to imagine the Great Chain, or its Paleyan derivative, as solely, or even primarily, a justification for oppression. It was, like so much of Western thought, a doctrine that allowed different interpretations and emphases and constituted one of the arenas of colliding values that have suffused Christian animal ethics.

\section{Animal Experimentation}

The collision of values is again clear in the centuries-long debate on animal experimentation. Traditionally, René Descartes is offered as the exemplar of the Christian rationalist tradition, treating animals as irrational machines on whom experimentation may be performed without fear of wronging them. In recent years, there has been a dispute as to whether Descartes allows for animal sensation ${ }^{25}$ but little disagreement about whether Descartes felt his theory justified his own animal experimentation or whether other animal experimenters used Descartes' views to justify their use of animals. Of perhaps greater importance, many modern commentators have asserted that Cartesianism has become the pervasive later attitude in the Western world. To take but one example, Jim Mason tells us that,

More than any other thinker, Descartes detached humanity from the natural world and set it up as the ruling class, aloof from and absolutely unrelated to its underlings. From him we get the thinking that prevails in the modern era - that of a human race so superior to the rest of nature that we are distinctly apart from it. $^{26}$

Mason's claim has some merit, but, in its hyperbole, it distorts both Descartes' view and, more emphatically, its role in the later Christian tradition. Thus, in a 1645 letter, Descartes' advice is that one should not "imagine ... the earth [made] for the bene.t of man, [nor attribute] to other creatures imperfections which do not belong to them, in order to raise himself above them." ${ }^{27}$ Moreover, many Christians were aghast at Descartes' apparent treatment of animals as nothing more than machines. Henry More, the celebrated Cambridge Platonist who greatly influenced Isaac Newton, accosted Descartes in a 1648 letter "with the internecine and cutthroat idea that you advance in the [Discourse on] Method, which snatches life and sensibility away from all the animals . .."28; and in his Metaphysical Colloquy of 1641 Pierre Gassendi, a Roman Catholic priest, ridiculed Descartes' illogical inconsistencies with regard to the rationality and sentience of animals. ${ }^{29}$ The very reason that we know that Port-Royal Jansenist vivisectors deemed the cries of their canine victims nailed to a board as "only the noise of a little spring that had been touched" is because of the ire the seminarians aroused. ${ }^{30}$ And Robert Boyle, the reputed English chemist, complained in 1686 that,

The veneration wherewith men are imbued for what they call nature has been a discouraging impediment to the empire of man over the inferior creatures of God: for many have not only looked upon it, as an impossible thing to compass, but as something impious to attempt. ${ }^{31}$

We should take at least as much note of the "many" who found the experiments "impious" as of the views of the experimenters.

Later, we may encounter Claude Bernard being aware of the animals on whom he experimented as nothing but organisms that conceal from him the problem he is seeking to resolve. Bernard's Introduction to the Study of Experimental Medicine (1865) convinced the medical community of the value of the artificial production of disease by chemical and physical means through reliance on animal models. ${ }^{32}$ Nonetheless, we should not imagine Bernard as the ultimate representative of an ongoing Cartesian victory. Those who were appalled at animal experimentation included Joseph Addison, Alexander Pope, Samuel Johnson, Victor Hugo, Christina Rossetti, Alfred Lord Tennyson, Thomas Carlyle, John Ruskin 
and C. S. Lewis. ${ }^{33}$ To take but a few examples, in To Mr. Congreve (1693), Jonathan Swift, the Dean of St. Patrick's, reflected and advanced public antipathies to the scientific passion for dissecting animals dead and alive. In Miscellanies I (1743), Henry Fielding, the novelist, penned a satirical and caustic parody on Experiments on the Cuttlefish by Abraham Tremblay, as reported in the proceedings of the Royal Society (407, January 1742/3). Robert Browning wrote two anti-vivisection poems ("Tray" (1879) and "Arcades Ambo" (1889)) and remarked further that he would "rather submit to the worst of deaths, so far as pain goes, than have a single dog or cat tortured on the pretence of sparing me a twinge or two." ${ }^{34}$ Robert Louis Stevenson strenuously opposed experiments on proverbial guinea pigs, even though the experiments were designed to provide a cure for a disease from which he suffered. ${ }^{35}$

If one follows the determinists, Marxian or otherwise, in understanding ideas and values in their economic and social context, one may recognize that the human health interests of the society, the professional and pecuniary interests of the experimenters, and the personal interests of the afflicted will have played a major role in determining their attitudes toward experimentation. Thus, their "unconscious identity with animals" (Jung) would have threatened their economic, social, and medical needs. Cartesianism provided a convenient philosophical rationalization. However, it would be unwarranted to conclude, as the above examples of opponents of animal experimentation reflect, that human self-interest was always dominant.

\section{The Complexity of the Conflicts}

In much of the recent intellectual discussion of Christian animal ethics, we encounter the assumption that the Christian voice is one. For example, several writers have referred to the Christian doctrine that animals do not have immortal souls. ${ }^{36}$ Certainly, Augustine and Thomas Aquinas, among many others, conform to the supposed doctrine, even though they acknowledge a minor level of obligation toward other species - Augustine telling us it would be inappropriate to kill even a fly to gain a coveted award ${ }^{37}$ and Aquinas praising the merits of kindness toward animals. ${ }^{38}$ Yet, the popular and influential kabbalist, Robert Flood (1574-1637), proclaimed that immortal souls inhabited animals as well as humans, a view reiterated by the devout William Wordsworth (among many other Romantics, including Coleridge and Southey) ${ }^{39}$ at the turn of the nineteenth century. In Man's Mortality (1643), Richard Overton, the revolutionary Puritan leveler, proclaimed, "all other Creatures as well as man shall be raised and delivered from death at the resurrection." ${ }^{40}$ The view was consistent with that of Arnobius and Origen in the early Christian years, John of the Cross in the sixteenth century, John Milton and the Cambridge Platonists (including Henry More) in the seventeenth, and repeated by the Reverend John Hildrop, the Reverend Richard Dean, and Leibniz in the eighteenth. Moreover, Bishop Joseph Butler, with Paley the most influential Anglican theologian of the eighteenth century, thought it a nigh certainty that animals had immortal souls while John Wesley, founder of Methodism, could see no reason why they would not. ${ }^{41}$ Stevenson thought dogs would be in heaven before any of us. Neither Christianity specifically, nor the Western mind generally, is in unison on the issue.

In fact, there are great varieties in attitudes to animals among, say, the Desert Fathers of the fourth century, the Albigensians of the twelfth, Franciscans of the thirteenth, Puritans of the seventeenth, official Catholics of the nineteenth, and Old Order Mennonites of the twentieth. In addition, there is considerable variety within each of these. Close identification with animals was relatively common among the Celtic saints but less so among the Italian saints. Thus, the Christian attitude to animals is, in the words of Linzey, "an ambiguous tradition." 42

As a generality, to which there are numerous exceptions, we may say the unsympathetic Fénelon position played the major (but not sole) role in Catholic thought, the sympathetic Goethian position found its major (but not sole) expression in evangelical and secular traditions. As late as 1984, the Roman Catholic Church was still reiterating the Aquinas-Fénelon message when Pope John Paul II announced, "it is 
certain that animals are intended for man's use," though that did not imply that we lacked certain fairly minimal obligations toward them. The Goethian image looms large in the explicitly Christian novels of the Brontë sisters, Dostoevsky, Victor Hugo and Tolstoy - covering Protestant, Orthodox, unofficial Catholic and unorthodox Christian viewpoints. When we look to early animal welfare legislation in Britain, evangelical Christians are its prime (but not sole) movers, aided by the pens of such established church animal welfare proponents as Richard Dean, Humphry Primatt, Thomas Young, and John Styles. ${ }^{43}$ Indeed, the early English Society for the Prevention of Cruelty to Animals, instituted to enforce the legislation, declared itself to be "conducted on exclusively Christian principles." 44

Thus far, in describing the conflicting Christian views of animals, we have tended to draw fairly simple battle lines and to locate different individuals on opposite sides - Boyle, Descartes and Bernard as supporters of vivisection and More, Swift and Johnson as opponents. With animal issues, however, we often see a degree of conflict or contradiction within the thinking of individuals, such that even writers commonly claimed as defenders of animal exploitation often have another side to them. Notoriously, St. Augustine paid little heed to animal interests, yet still avowed that

All things, which are, are good . . . beasts and all cattle, creeping things and fowls of the air ... praise Thy name. . . I decided that all things above were better than those below, but that both together were better than the things above alone."

Equally notoriously, Immanuel Kant insisted that "Animals are not self-conscious, and are there merely as a means to an end. The end is man." Yet Kant appears less confident of this conclusion when he adds, "the more we come into contact with animals the more we love them, for we see how great is their care for their young." Further, William Leiss, in Domination of Nature, tells us that Francis "Bacon's great achievement was to formulate the concept of human mastery over nature much more clearly than had been done previously and to assign it a prominent place among men's concerns. ${ }^{\text {"46 }}$ Nonetheless, that selfsame Bacon around 1597 commended "Charity" to animals, and complimented the Turks because they "are kind to Beasts, and give Alms to Dogs and Birds." He averred that "The inclination of Goodness is imprinted deeply in the nature of Man; insomuch that, if it issue not toward Men, it will take unto other living creatures." This he acknowledged a part of the "Goodness of Nature."

To summarize, within Christian thought we see a history of conflict and contradiction that defies any simple classification. Some of the conflicts involve different denominations with different views about the human-animal relationship. However, within denominations, there also have been competing views, and sometimes the debate has occurred within individual souls.

\section{Concluding Remarks}

Biblical and Christian thought presents us with a complex view of the status of animals. At a fundamental level, animals are viewed through a pastoralist lens, whereby certain use of animals is seen as legitimate while diligent care of animals is highly valued. Nonetheless, Christianity shares with a number of other religions the belief that all creatures are God's creatures and recipients of divine concern. How these beliefs are to be interpreted and translated into action has been the subject of recurring debate. It has been a debate influenced by economic forces, ecclesiastical institutions, sheer individual and collective self-interest, as well as by honest, legitimate, and well-considered differences of interpretation. The result has been and likely always will be a lack of consistency.

In describing the complexity of Biblical and Christian thought about animals, we are not claiming that human treatment of animals in the West is, or has been, salutary. Nonetheless, setting the record straight has important practical implications. If, as some have claimed, Christianity gives humans license to 
dominate and exploit nonhuman animals at will, then any significant reform in our treatment of animals would require a repudiation and reversal of the West's most influential religion. But if, as we argue, the Christian tradition is more complex, in many cases emphasizing both human and divine care of animals while legitimizing certain forms of animal use, then at least some reforms would require that the Christian West collectively remember, rather than repudiate, its most fundamental principles of animal ethics.

\section{Notes}

1. Correspondence should be sent to Rod Preece, Department of Political Science, Wiflrid Laurier University, Waterloo, ON, Canada, N2L 3C5 or David Fraser, Faculty of Agricultural Sciences and Centre for Applied Ethics, University of British Columbia, 2357 Main Mall, Vancouver, BC, Canada, V6T 1Z4. We are indebted to Rev. Dr. Gary Hauch and Rev. Dr. Terry Anderson for helpful and incisive comments on the initial draft of this paper; and to Paul Waldau and an anonymous reviewer for sound yet friendly critiques of the originally submitted paper.

2. Edward Payson Evans, Evolutional Ethics and Animal Psychology, New York: D. Appleton, 1897; Lynn White, Jr., 'The Historical Root of Our Ecologic Crisis,' Science, 155, 1967, 1203-7; Peter Singer, Animal Liberation, 2nd edition, New York: New York Review of Books, 1990; Roderick Frazier Nash, The Rights of Nature: A History of Environmental Ethics, Madison: University of Wisconsin Press, 1984. In a much more perceptive interpretation of Biblical views, Schochet refers to domestic animals as "the delicate tool" (63), while noting that this utilitarian attitude was balanced by feelings of compassion for, and kinship with, animals. Elijah Judah Schochet, Animal Life in Jewish Tradition: Attitudes and Relationships, New York, KTAV Publishing House, 1984, 46-79.

3. This is the King James version of Genesis 1,26 , the one traditionally used by those who denounce the Christian tradition. As we shall see, interpretative translation is a constant difficulty, especially with regard to 'dominion'. Hereafter, we shall employ the New English Bible translation for Biblical quotations.

4. For a learned discussion of the concept and its relation to justice, see Robert Murray, The Cosmic Covenant: Biblical Themes of Justice, Peace and the Integrity of Creation, London: Sheed and Ward, 1992.

5. John Passmore, Man's Responsibility for Nature: Ecological Problems and Western Traditions, London: Duckworth, 1974, 9.

6. Andrew Linzey, Christianity and the Rights of Animals, New York: Crossroad, 1991, 25-28.

7. James Thomson, The Seasons and The Castle of Indolence, ed. James Sambrook, New York: Oxford University Press, 1972, 9, Seasons, 'Spring,' line 241; John Brown, Self-Interpreting Bible, Glasgow: Blackie, 1834 (1776), 2: George Nicholson, George Nicholson's On the Primeval Diet of Man (1801): Vegetarianism and Human conduct Toward Animals, ed. Rod Preece, Lampeter: Mellen, 1999, 12; John Ritson, An Essay on Abstinence from Animal Food as a Moral Duty, London: Richard Phillips, 1802, 164; Anne Brontë, Agnes Grey, London: Penguin, 1988 (1847), 105-6; Thomas Young, An Essay on Humanity to Animals, London: T. Cadell and W. Davies, 1798, 9-33; Victor Hugo, Les Misérables, trans. Norman Denny, London: Penguin, 1982 (1862), 81.

8. Theodore Hiebert, The Yahwist's Landscape: Nature and Religion in Early Israel, New York: Oxford University Press, 157. Hiebert explains that the Pentateuch is thought to consist of "a combination of four different sources or documents, authored by four different writers living at different times in Israelite history." (24) The oldest have been attributed to the Yahwist and are designated J. These older narratives, it is hypothesized, "were later incorporated into a new edition of Israel's beginnings prepared by Priestly Writer(s)/Editor(s) (abbreviated P)." (24)

9. It has become customary to give dates as c.e. (common era) or b.c.e. (before common era). However, the commonality is restricted to the Abrahamic tradition. The terms could thus appear demeaning to all outside that tradition. While $B C$ and $A D$ are also agenda laden, it is now well known 
that they do not coincide with the birth of Christ, and are thus artificial, almost arbitrary, and, in our view, for that reason preferable.

10. See George Boas, Primitivism and Related Ideas in the Middle Ages, Baltimore: Johns Hopkins, 1997 (1948), 187-8.

11. Homily 39 on the Epistle to the Romans.

12. C. G. Jung, Memories, Dreams, Reflections, New York: Vintage, 1985 (1963), 101.

13. For a lengthy list, see E. S. Turner, All Heaven in a Rage, Fontwell: Centaur, 1992, (1964), 25; and for an entirely separate one, Rod Preece, Animals and Nature: Cultural Myths, Cultural Realities, Vancouver: UBC Press, 1999, 127.

14. E. S. Turner, All Heaven in a Rage, 57, notes that medieval cockfights on their premises were acquiesced in by the church. It should be added, however, that the clergy were forbidden to participate.

15. Arthur O. Lovejoy, The Great Chain of Being: A Study of the History of an Idea, New York: Harper \& Row, 1965 (1936), viii.

16. David Maybury-Lewis, Millennium: Tribal Wisdom and the Modern World, New York: Viking, 1992, 36, 37.

17. Richard Milner, The Encyclopedia of Evolution: Humanity's Search for Its Origins, New York: Henry Holt, 1990, 201.

18. Quoted in Arthur O. Lovejoy, The Great Chain of Being, 187.

19. See Seamus Deane's notes to James Joyce, A Portrait of the Artist as a Young Man, London: Penguin, 1993, 324.

20. See Rod Preece, Animals and Nature, 120-121.

21. Priscilla Wakefield, Instinct Displayed in a Collection of Well-Authenticated Facts, exemplifying the Extraordinary Sagacity of Various Species of the Animal Creation, 4th edition, London: Harvey and Darton, 1821 (1811), passim, but initially viii.

22. John Locke, Essay Concerning Human Understanding, London: H. Hills, 1710 (1690), vol. 2, 49.

23. Nicholas Boyle, Goethe: The Poet and the Age, Oxford: Oxford University Press, 1992, vol. 1, 399.

24. For John Ray, see Wisdom of God Manifested in the Works of Creation, New York: Garland, 1979 (1691); for Gilbert White, see The Natural History of Selborne, London: Folio Society, 1962 (1789); for William Cowper see The Task (1785).

25. See John Cottingham, A Descartes Dictionary, Oxford Blackwell, 1993 and A. Denny, Descartes' Philosophical Letters, Oxford: Clarendon, 1970, for the affirmative case, and Gary Steiner, 'Descartes on the Moral Status of Animals,' Archiv für Geschichte der Philosophie, 80, 3, 1998, 268-291, for the negative.

26. Jim Mason, An Unnatural Order: Uncovering the Roots of our Domination of Nature and Each Other, New York: Simon and Schuster, 1993, 37.

27. For a fuller version of the letter see Rod Preece, Animals and Nature, 120.

28. Quoted in Gary Steiner, 'Descartes on the Moral Status of Animals,' 268. The Latin original is at n. 1.

29. Pierre Gassendi, Metaphysical Colloquy, or Doubts and Rebuttals concerning the Metaphysics of René Descartes with his Replies (1641), Rebuttal to Meditation 2, Doubt 7, in The Selected Works of Pierre Gassendi, trans. Craig B. Brush, New York: Johnson Reprint Corporation, 1972, 197-8.

30. Nicolas Fontaine, Mémoires pour servir à l'histoire de Port Royal, Cologne, 1738, quoted in L. Rosenfield, From Beast-Machine to Man-Machine: The Theme of Animal Soul in French Letters from Descartes to La Mettrie, London: Oxford University Press, 1940.

31. Quoted from Robert Boyle, A Free Inquiry into the Vulgarly Receiv'd Notion of Nature in Peter J. Bowler, Norton History of the Environmental Sciences, New York: W. W. Norton, 1993, 89.

32. See Rod Preece and Lorna Chamberlain, Animal Welfare and Human Values, Waterloo: Wilfrid Laurier University Press, 1993, 53-54. 
33. Joseph Addison, The Spectator, no. 120, 18 July, 1711; Alexander Pope, The Guardian, no. 61, 21 May, 1713; Samuel Johnson, The Idler, no. 17, 5 August, 1758; Victor Hugo: Gordon Robb, Victor Hugo: A Biography, New York: W. W. Norton, 1998; Christina Rossetti: Jan Marsh, Christina Rossetti: A Literary Biography, London: Pimlico, 1994, 433 ff. References to Tennyson, Browning, Carlyle and Ruskin may be found at the same source; C. S. Lewis discussed the issue in That Hideous Strength (1945) and wrote a leaflet, c. 1950, for the National Anti-Vivisection Society. For the latter, see Richard D. Ryder, Animal Revolution: Changing Attitudes towards Speciesism, Oxford: Basil Blackwell, 1989, 10-11. One might add that the deist or occasional Christian Voltaire, Mark Twain, Thomas Hardy, and Wilkie Collins (who devoted a whole novel to the issue: Heart and Science (1883)) were also anti-vivisectionists.

34. Quoted in Donald Thomas, Robert Browning: A Life Within a Life, London: Weidenfeld and Nicolson, 1989, (1982), 263.

35. See Frank McLynn, Robert Louis Stevenson, London: Pimlico, 1994, (1993), 282.

36. See, for example, Peter Singer, Animal Liberation, 200; Angus Taylor, Magpies, Monkeys, and Morals: What Philosophers Say about Animal Liberation, Peterborough: Broadview, 1999, 23; Barbara Noske, Beyond Boundaries: Humans and Animals, Montreal: Black Rose Books, 1997, 46.

37. Augustine, Confessions, London: Longman's Green, 1897, bk. 4, ch. 3, 72.

38. Aquinas, Summa theologiae, vol. 2, 1, 102, 6, 106. For a more sophisticated than customary treatment of Aquinas on animal souls, see Andrew Linzey, Christianity and the Rights of Animals, 3639.

39. S. T. Coleridge, A Lay Sermon (1817) in The Collected Works of Samuel Taylor Coleridge: Lay Sermons, ed. R. J. White, London: Routledge \& Kegan Paul, 1972, 183, n. 6; Robert Southey, 'On the Death of a Favourite Old Spaniel', Poems, Bristol: John Cottle, 1797.

40. Richard Overton, Man's Mortalitie, ed. Harold Fisch, Liverpool: Liverpool University Press, 1968, 68.

41. Arnobius, Adversus Nationes, 2, 16-17; Saint John of the Cross, The Complete Works, trans. A. E. Peers, Wheathamstead: Anthony Clarke, 1974, vol. 2, 5; John Hildrop, Free Thoughts upon the Brute Creation, London, 1742; Richard Dean, An Essay on the Future Life of Brutes, introduced with Observations upon Evil, Its Nature and Origin, Manchester, 1767, 2 volumes; Gottfried Wilhelm Leibniz, Monadology, and other philosophical writings, Indianapolis: Bobbs Merrill, 1964 (1714), sec. $82 \mathrm{ff} ., 265 \mathrm{ff}$.; Joseph Butler, The Analogy of Religion, Natural and Revealed, to the Constitution and Course of Nature, London: Longman \& Co., 1834 (1736), 13-30; John Wesley, The General Deliverance (1788) in Sermons on Several Occasions, London: Wesleyan Conference Centre, 1874, 281-6; Alexander Pope, who denied immortal souls to animals, believed we owed them a special consideration on earth precisely on that account.

42. Andrew Linzey, Christianity and the Rights of Animals, 22.

43. Richard Dean, An Essay on the Future Life of Brutes, 1767; Humphry Primatt, The Duty of Mercy and the Sin of Cruelty to Brute Animals, ed. Richard D. Ryder, Fontwell: Centaur, 1992 (1776); Thomas Young, An Essay on Humanity to Animals, 1798; John Styles, The Animal Creation: Its Claims on Our Humanity Stated and Enforced, London: T. Ward, 1839.

44. See A. W. Moss, Valiant Crusade: The History of the Royal Society for the Prevention of Cruelty to Animals, London: Cadell, 1961, 28.

45. Augustine, Confessions, bk. 7, ch. 12, 179; ch. 13, 180.

46. William Leiss, The Domination of Nature, Montreal \& Kingston: McGill-Queen's Press, 1994 (1972), 48.

47. Francis Bacon, Essays, London: R. Chiswell, 1706 (c. 1597), 30-31. 